\title{
Mastery of Mining on Ulayat Land / Indigenous Land
}

\author{
Putu Dy atmikawati \\ Dwijendra University Bali \\ Denpasar, Bali, Indonesia \\ armydewi@gmail.com
}

\begin{abstract}
Law no. 4 of 2009 on mineral and coal mining in its consideration states that "the minerals and coal contained in the territory of Indonesian mining law are non-renewable natural resources, therefore the management must be controlled by the $S$ tate to provide real added value to the national economy" The word is controlled by the state becomes a phenomenon in this case on the basis of such controlled government can take over the ulayat land / customary land in which it contains mineral and coal mining. With the event of taking over the land of ulayat / adat land by the government which contains mineral and coal mining, it becomes a conflict between indigenous and tribal peoples with investors and the government in the absence of dialogue and repressive approach. The controlling of mining on customary / communal lands has juridical foundation namely Article 18 letter b paragraph 2 of the Constitution of the Republic of Indonesia of 1945 Article 2 paragraph (4) and Article 5 of Law no. 5 of 1960 on the Basic Regulations of Agrarian Principles. An ulayat right is a right of legal partnership of the land inhabited while its exercise is carried out by the legal community itself or by the head of the fellowship in the name of the fellowship. The territory of the communion is the property of an essentially fixed partnership, ie the transfer of property rights to this territory is not permissible. Ulayat land / customary land is part of ulayat right. In principle, the land required for mining businesses located on customary communities of customary law, mining entrepreneurs shall conduct consultations with indigenous and tribal peoples to obtain an agreement on the delivery of land and the remuneration.
\end{abstract} Land

Keywords- Mastery, Mining, Ulayat Land / Indigenous

\section{INTRODUCTION}

\section{A. Background Issues}

Based on the provisions of article 1 number 1 of Law no. 4 of 2009 concerning mineral and coal mining formulating Mining is part or all of the phases of activities in the framework of mineral, coal and coal research, management and exploitation covering general investigation, exploration, feasibility study, construction, mining, processing and refining, transportation and sales, pascatambang.

The provisions of article 1 point 1 of Law no. 4 of 2009 on mineral and coal mining becomes the basis by the government in mining business, which in its consideration states that "the mineral and coal contained in the territory of Indonesian mining law are non renewable natural resources, therefore the management must be controlled by the State to provide added value in tangible for the national economy. "
The word is controlled by the state to be a phenomenon in this case on the bas is of such controlled government can take over customary land / customary land in which it contains mineral and coal mining.

Mining permits are mushrooming in various regions, not behind in North Maluku. Worse, these licenses do not heed the existence of indigenous peoples. Inevitably, half of the land area of the mining province is partly in the territory of indigenous peoples.

Their lives are increasingly displaced. From the mainland, the area of Malut 3,327,800 hectares (33,278 $\mathrm{km} 2$ ). Note The Alliance of Indigenous Peoples of the Archipelago (AMAN) Malut, over 2 million hectares into mining with 335 permits. From there, there are three mining companies holding contracts of work. Namely, PT Aneka Tambang (Antam), PT Weda Bay and PT Nusa Halmahera Minerals (NHM). The rest, mining permits by regions.

The phenomenon of land disputes arose surface which mostly resulted from the procurement of land for the benefit of infrastructure, land disputes mostly occur between indigenous and tribal peoples with the owners of capital and government agencies concerned.

The existing customary law in some regions of Indonesia must still be fully acknowledged and held by the community. One of the sectors of Indonesian customary law which enjoys a privileged status compared to other customary law sectors is the ulayat lands, as this ulayat land after the coming into effect of Law no. 5 of 1960 on the Basic Regulation of Agrarian Principles has been the basis of the National Agrarian Law.

With the event of taking over the land of ulayat / adat land by the government which contains mineral and coal mining, it becomes a conflict between indigenous and tribal peoples with investors and the government in the absence of dialogue and repressive approach. From the background, the author examines how the control of mining on ulayat land / customary land.

\section{B. Problem Formulation.}

How to control mining on ulayat land / customary land?

\section{Writing Method.}

In order for a paper based on research to be said to meet the krIteria as a scientific work, then needed a method. In relation to this matter, in the preparation of this paper, the 
author uses normative juridical method of research legislation and literature analysis and other legal materials such as books and legal journals.

\section{DISCUSSION}

An ulayat right is a right of legal partnership of the land inhabited while its exercise is carried out by the legal community itself or by the head of the fellowship in the name of the fellowship. The territory of the communion is the property of an essentially fixed partnership, ie the transfer of property rights to this territory is not permis sible. Ulayat land / customary land is part of ulayat right.

In principle, the land required for mining businesses located on customary commun ities of customary law, mining entrepreneurs shall conduct consultations with indigenous and tribal peoples to obtain an agreement on the delivery of land and the remuneration. However, it is sometimes denied on the basis of the urgent interests of investors and immediately provide unneces sary compensation.

Article 1 number 1 of Law no. 4 of 2009 concerning mineral and coal mining formulating Mining is part or all of the phases of activities in the framework of mineral, coal and coal research, management and exploitation covering general investigation, exploration, feasibility study, construction, mining, processing and refining, transportation and sales, pascatambang.

The provisions of article 1 point 1 of Law no. 4 of 2009 on mineral and coal mining becomes the basis by the government in mining business, which in its consideration states that "the mineral and coal contained in the territory of Indonesian mining law are non renewable natural resources, therefore the management must be controlled by the State to provide added value in real for the national economy. "The word is controlled by the country into a phenomenon in this case on the basis of being mastered the government can take over customary land / customary land which contains mineral and coal mining.

Mastery of mining on customary land, in the opinion of the author has a juridical foundation, namely article 18 letter b paragraph 2 of the 1945 Constitution of the State of the Republic of Indonesia which states "the State recognizes and respects the unity of indigenous and tribal peoples along with their traditional rights still alive and in accordance with the development of society and the principles of the Unitary State of the Republic of Indonesia, as governed by the law ".

Understanding the formulation of article 18 point $b$ paragraph 2 of the 1945 Constitution of the State of the Republic of Indonesia then:

1. The Constitution guarantees the unity of indigenous peoples and their traditional rights;

2. The constitutional guarantee as long as the customary law is still alive;

3. In accordance with the development of society;

4. In accordance with the principle of the Unitary State of the Republic of Indonesia; and

\section{Arranged in legislation.}

Therefore, this Constitution guarantees the recognition and respect for the control of mining on customary land / customary land if it meets the condition of reality, that is customary law is still a live and according to the development of society and the Ideality requirement, that is in accordance with the principle of the unitary state of the Republic of Indonesia and the applicability of the law - invite.

Tenure of mining on customary land / customary land may refer also to the provisions of Article 2 paragraph (4) of Law no. 5 of 1960 on the Basic Regulations of the Agrarian Principles provides that "the right of control of the State above its execution may be authorized to the Swatantra and customary law communities, as necessary and not contrary to the national interest, in accordance with the provisions of the Government Regulation ". Article 5 of Law no. 5 of 1960 on the Basic Regulations of the Agrarian Principles mentioned that the agrarian law that applies to the earth, water and space is customary law. From the provisions of the article as a basis for the control of mining on customary land / customary land.

From the formulation of Article 18 letter b paragraph 2 of the 1945 Constitution of the State of the Republic of Indonesia and Article 2 paragraph (4) of Law no. 5 of 1960 on the Basic Regulation of Agrarian Principles, basically Law no. 4 of 2009 on mineral and coal mining is not appropriate if it is contradictory to Article 18 letter b paragraph 2 of the 1945 Constitution of the Republic of Indonesia and Article 2 paragraph (4) of Law no. 5 of 1960 on the Basic Regulations of Agrarian Principles.

Objects of community rights over their customary territories (hak ulayat) are land, water, plants, and animals as customary rights. Territory has clear boundaries either factually (natural borders or signs on the ground) or symbolic (audible gong sounds). Managing and determining relationships can be seen easily whether land transactions are conducted by customary rules and institutions. The authority of indigenous peoples is not merely over the object of the land, but also of other natural resources objects that are all on the ground (trees, animals, rocks that have economic significance); in the soil of excavated materials), as well as along the coast, as well as on the surface of the water, in the water or on the ground within it.

The occupied land has a magical-religious relationship. This relationship causes the customary law community to acquire the right to control the land, to use the land and to collect the produce from the plants and animals that live on it.

Justice according to Plato, justice exists in the law made by the state is the only source of law, all aspects of individual life under the supervision of law and state administration, justice is good in the sense of harmony and balance. Justice needs balance, harmony and harmony between personal interests, common interests or the interests of the people, including the state.

In the context of the control of mining on customary land / customary land based on the principle of justice, the theory of justice put forward by Plato and John Rawls can be it is unders tood that the state, the government as the supervis or of the law and the administration of the state, is obliged to implement the principle of good justice in the sense of harmony and balance between the government and the society and / or customary law community, the existence of customary land tenure in indigenous and tribal peoples must be harmonious and balanced, ulayat land in customary law 
community needs balance, harmony, and harmony between personal interests, common interests or interests of the community, including the State.

\section{SUMMARY}

\section{A. Conclusions}

Mining companies to be able to mine must have permission from the government first. Meanwhile, in general, land rights are given by the government in comparison with mining rights. Based on the legal rules of mining, a new mining permit can be done if the land rights is sue has been resolved first and adjusted to the basic rules of agrarian. This means that if a company and the government to be able to conduct mining in the territory of ulayat land / customary land must first consult with indigenous peoples, in this case the control of mining on ulayat land / customary land, has a juridical basis that is article 18 letter b paragraph 2 Of the 1945 Constitution of the State of the Republic of Indonesia which states "the State recognizes and respects the unity of indigenous and tribal peoples along with their traditional rights as long as they are alive and in accordance with the development of society and the principles of the Unitary State of the Republic of Indonesia, as governed by the law" and Article 2 paragraph (4) of Law no. 5 of 1960 on the Basic Regulations of the Agrarian Principles provides that "the right of control of the State above its execution may be authorized to the Swatantra and customary law communities, as necessary and not contrary to the national interest, in accordance with the provisions of the Government Regulation ". Article 5 of Law no. 5 of 1960 on the Basic Regulations of the Agrarian Principles mentioned that the agrarian law that applies to the earth, water and space is customary law. From the provisions of the article as a basis for the control of mining on customary land / customary land.

\section{B. Suggestions}

The need for synergy between government, customary law community and mining company investors in mining processing located on customary land / customary land, in this case the government and investor of mining company can approach persuasive and form a communication forum so that customary law community can menyampaiakan his positive will is related to the processing of mining, meaning that the government and investors of mining companies can embrace indigenous and tribal peoples as partners rather than as workers and provide a balance of justice in the distribution of mining proceeds for the common prosperity.

\section{REFERENCES}

[1] Dominikus Rato, 2015, Contemporary Adat Law, Laksbang Justitia, Surabaya.

[2] HerowatiPoesoko, M. Khoidin, \& Dominic Rato, 2014, Existence of Customary Court in Justice System In Indonesia, LaksBang Justitia, Surabaya.

[3] Kusworo, 1999, How the Rights of Indigenous Peoples Community in Managing Natural Resources Regulated, ICRAF, Bogor.

[4] Maria Kaban, 2004, Existence of indigenous peoples' rights to land in T anah Karo, USU Reposit ory, North Sumatra.

[5] Wignodipuro Berojo, 1987, Introduction and Principles of Indigenous Law of Indonesia, Masagung, Jakarta. 